\title{
Using Descriptive analysis to Assess the Psychosis Mental Health Effect of Intimate partner Violence in Obudu, Cross River State, Nigeria
}

\author{
Esther P. Archibong ${ }^{\mathrm{a},}{ }^{,}$, Sylverster Akomaye ${ }^{\mathrm{b}}$, Egbe Tangban $^{\mathrm{a}}$, Mary U. Ojong-Ejoh ${ }^{\mathrm{b}}$, \& \\ Adeolu Ayodele ${ }^{\mathrm{c}}$ \\ ${ }^{a}$ Department of Social Work, University of Calabar, P.M.B.1115, Calabar, Nigeria \\ ${ }^{b}$ Department of Sociology, University of Calabar, P.M.B.1115, Calabar, Nigeria \\ ${ }^{c}$ Birmingham University, United Kingdom
}

\begin{abstract}
The present study is aimed at using descriptive analysis to examine the mental health effect of Intimate Partner Violence on women in Obudu Local Government Area of Cross River State. Data was collected from a population of women aged 18 and above in Obudu Local Government Area, using structured questionnaire. the sample size for the study was 473, which was arrived at using the Survey Monkey Sample Size Determinant Technique. The sample for the study was arrived at using the cluster and purposive sampling technique. Descriptive analysis was used to analyze the data collected from the field. Result revealed that A significant percentage $(36.41 \%)$ women suffer abuse very often with majority $(41.75 \%)$ suffering both physical and emotional abuse. In the last 12 months, 22.09 percent of the women have suffered abuse from an intimate partner and 16.50 percent of the victims needed medical attention after abused. On the mental health effect of abuse on the victim only 9.47 percent of women reported not suffering from any mental health illness after being abused by an intimate partner. 34.47 percent of women suffered from depression as as result of abuse, 23.79 percent suffered from anxiety disorder, 20.63 percent suffered from mood disorder. 2.43 percent suffered from suicidal ideation, 1.70 percent suffered from post-traumatic stress disorder and 7.53 percent suffering from other mental health issues. The study conclude that intimate partner violence significantly causes mental health issues. Hence there is need for increase public awareness on the dangers of intimate partner violence by government and appropriate laws that target rural communities should be put in place to combat the problem.
\end{abstract}

Keywords: Intimate Partner Violence, Mental health, Descriptive analysis, Obudu.

\section{Introduction}

Violence against intimate partner is a global health problem that violates the rights of person. Intimate partner violence refers to behavior in any intimate relationship that causes psychological, physical or sexual harm to those in the relationship, especially women (WHO, 2002) According to United Nation Women, (2021) reports that available data reveals that an estimate 736 million women suffers from one form of violence or another from intimate partner or non-partner at least once in their lifetime. The world health organization (2021) reports that one in every three women representing 30 percent of women globally have experience either physical, sexual or psychological abuse from either an intimate partner or a non-intimate partner in their lifetime. The world health organization (2021) reports also assert that an estimate one third of the women ages 15 to 45 years that have been in an intimate relationship reported suffering from one form of violence from their intimate partner.

Existing reports point to the fact that intimate partner violence is prevalence in developing nations such as those found in sub-Saharan Africa (Abraham, Jewkes, Laubsecher \& Hoffman, 2006; Izugbara, Obuyan, Degfri \& Bhatti, 2020; United Nation Population Fund, 2019). In sub-Saharan Africa, around 20 percent of women aged 18 and 24 years of age have reported sexual violence from an intimate partner (UNFPA. 2019), In war and conflict prone nations such as Democratic Republic of Congo, Mozambique, Zimbabwe and Uganda, intimate partner violence is prevalence (Akinkorah, Drekson \& Seidu, 2018; Barebo, Schumann, \& Vaezghasemmi, 2018). The United Nation (2020) reports

* Corresponding author.

E-mail address: espat@unical.edu.ng 
that in Nigeria, the lifetime prevalence of intimate partner violence stands at 17.4 percent. The Nigerian demographic and health survey (2014) asserts that 11 percent of women aged 15 to 49 have experienced one form of either physical or sexual violence in the last 12 months (Berebo, Schumann, \& vaezghasemi. 2018; Berebo, Omudaji \& Odumegwu, 2002: Tanimu, Yohamma \& Omeiza, 2016; Okenwa, Lamoko \& Janson,2009; Omang, Angioha, Ojong-Ejoh \& Abang, 2020). The National Health Survey (2018) in Nigeria reported that almost one in every three women, accounting for 31 percent of female population in Nigeria aged 15 and 49 have experienced physical violence in their lifetime, with 14 percent experiencing it in the last 12 months alone. 49 percent of the women who have been married have experienced intimate partner violence when compared when compared to 36 percent of women who never married. 9 percent of women aged 15 to 49 have experienced sexual violence in their lifetime, with 4 percent of women experiencing it in the last year alone. 4 percent of experienced it before the age of 18 (DHS,2018). In terms of geographical location, intimate partner violence is prevalent in the north east (28 percent), while south west and north east has a prevalent rate of 12 percent each.

Violence among intimate partner can significantly impact a woman's mental health and well-being throughout her life, even long after the violence has stopped (Dokkedahl, Kok, Murphy, Kristensen, Bech-Hansen \& Elkelit, 2019; Ruiz-Perez \& Plazaola-Castaro,2005; Mechanic, Weaver, \& Rebick, 2008' Coker, Davis, Awas, Desai, Sanderson, Brandit \& Smith, 2002). Ali Mogren and Kranz (2013) on the intimate partner violence and mental health of married women in Karachi, Pakistan found from data collected from 759 women between the age of 25 and 60 that intimate partner violence leads to suicidal thoughts. Mechanic, Weaver and Resick (2008) in their study that test the effect of psychological abuse on mental health outcome using hierarchical regression found that psychological abuse significantly contributes post-traumatic stress disorder and depression. Navaro-Mautas, De Lemus and Megrias (2021) conducted a national survey on the mental health outcome of intimate partner violence. Result revealed that women who experienced intimate partner violence show signs of poor mental health and suicidal ideation. Chepuka, Taegtmever, Chorwe-Sungami, Mambulsa, Chiwa, Tolhurst (2014) used indept interview and focus group discussion to collect data from participants on the mental health impact of intimate partner violence in Malawi. Result revealed that participants reported mental health impact of intimate partner violence.

Obudu, like other rural societies in developing nations is patriarchy, where the traditional believe is that women are the property of their husbands and are treated as subordinates to their male counterparts, and the incidence if intimate partner is high but are rarely reported. Women prefers to suffer in silence than been seen as a pariah or irresponsible and unable to keep their marriage or relationship. This study seeks to examine the mental health effect of intimate partner violence in Obudu local government area, Cross River State, Nigeria

\section{Materials and Methods}

\subsection{Study Design}

The quantitative descriptive method using a semi structured questionnaire to allow an indept analysis of participants knowledge on the mental health effect of intimate partner violence was adopted for the study. The method allows the researcher to describe a situation, population or phenomenon using descriptive statistics systematically and accurately. The questionnaire contained 9 items that was designed to elicit needed information for this study.

\subsection{Study Settings}

The study was conducted between January and March 2021 in Obudu Local Government Area of Cross River State. Obudu is one of the 18 local government area in cross river state. Situated in the northern part of the state in the southern Guinea savanna zone. Covering an area of 379.164 square kilometre, the Local Government Area is under lain by basement rocks that marks the western end of the foothills of the Cameroonian mountains (Oko, Egbai \& Ankpo, 2021). The local government area is sandwiched between Ogoja Local Government Area in the West, Obanliku in the East, Benue State to the North and Boki to the South. Obudu Local Government Area is made up of five indigenous communities: Bette, Alege, Ubang, Utugwang and Ukpe (Ojong -Ejoh, Iji \& Angioha, 2019). According to the last official population census of 2006, the population of Obudu stands at 161,459 (NPC,2006). Officially, the population of women in the local government is 79,920 (city population. 2017). It is from this population that the participants for this study will be drawn from. 


\subsection{Participants Recruitment}

473 participants were selected from the population of 79,920 women in Obudu Local Government Area. The sample size was arrived at using the Survey Monkey Sample Size Determinant Technique. Obudu was divided into ten clusters, according to the wards that makes up the local government area from the ten clusters, five wards were selected using purposive sample technique. The selected clusters are; cluster 1: Obudu Urban 1, cluster 2: Obudu Urban 2, cluster 3: Utugwang Central, cluster 4; Ukpe, cluster 5; Begianding. From the five selected wards, 3 communities were selected using also the purposive sampling. The selected communities are highlighted in table 1. From the selected communities, 32 participants were selected from 8 communities and 31 from 7 communities using the purposive sampling technique. The criteria for selection are that the participants must be female, must be above 18 years and must have been in an intimate relationship for more than 5 months and must have been abused.

Table 1. Showing Participant Recruitment

\begin{tabular}{llll}
\hline S/N & Wards & Selected Communities & Sample size \\
\hline 1 & Obudu Urban I & Abonkib & 32 \\
& & Udigie & 32 \\
2. & Ipong & Bebuawhan & 32 \\
& & Kakum & 32 \\
& & Bebuaghbong & 32 \\
3. & Utugwang Central & Bebuabie & 32 \\
& & Rikwen & 31 \\
4. & Begiading & Ukpirinyi & 31 \\
& & Ejagbe & 31 \\
& & Kutiang & 32 \\
5. & Ukpe & Betukwel & 31 \\
& & Igwo & 31 \\
& & Ashipke & 31 \\
& & Owong & 32 \\
\end{tabular}

Source: Field survey, 2021

\subsection{Ethical Consideration}

An ethical letter of approval was obtained from office of the Obudu Local Government Area chairman for approval. The researcher also obtains verbal approval from the participants, who were assured of the safety and anonymity of all information supplied.

\subsection{Data Collection and Analysis Procedure}

Sampling procedure, instrument administration was first subjected to a pilot test involving 50 women who were not original part of the research participants to assess clarity, acceptability, relevance and to the variables under study. Feedback for the pilot participants was used to make acceptable changes to the instrument and the selection procedure of the real participants. Data collection was carried out with the aid of five research assistants, who were taught on the ethics and procedure of data collection. The researchers and the research assistants divided themselves into five groups of two each and each group collected data from each of the wards. Each of the instrument was checked for errors and the classified presented and analyzed using descriptive statistics.

\section{Results and Discussions}

Data collected to check the impact of intimate partner violence on mental health were analyzed using descriptive statistics which were reported using frequency distribution counts, tables, and graphs. out of the 473 distributed instruments, only 412 was return and this figure was used for analysis 


\subsection{Results}

\subsubsection{Presentation of Demographic and Relationship Status of Participants}

Participants Demographic and Relationship status revealed thus: out of the 412 participants, 83(20.15\%) were between of ages of 18 and 25 years, 135 (32.77\%) were between the ages of 26 and 32 years, $129(31.31 \%)$ were between ages of 33 and 39 years, $38(9.22 \%)$ were between the ages of 40 and 47 years and $27(6.55 \%)$ were aged 48 and above. In term of the educational status of participants, 179 participants representing 43-35 percent had at least SSCE, this is followed by 162 participants, representing 39.32 percent who had attended a tertiary institution, followed by 52 participants representing 12.62 percent, who had at least first school leaving certificate (FSLC) and then 19 participants representing 4.61 percent who had a post-graduate degree.

A large majority of the participants, 153 representing 37.14 percent were married, 103 participants representing 25.00 percent were single, this is followed by 77 participants representing 18.69 percent who were separated from their husbands. Then there is 54 participants representing 13.11 percent who were divorced and finally 7 participants representing 1.7 percent who were widowed. 253 participants representing 61.41 percent of the participants are currently living with the perpetrators of abuse, with 159 representing 38.59 participants not living with them. On the length on relationship with perpetrators, 161 participants representing 39.08 percent reported less than one year, 147 participants representing 35.68 percent reported between 1 and 5 years, 93 participants representing 22.57 percent reported between 6 and 10 years, with only 11 participants representing 2.67 percent reporting more than 10 years.

On length of abuse: 175 participants representing 42.48 percent reported between 1 and 5 years, 114 participants representing 27.67 percent reported between 6 and 10 years, 102 participants representing 24.76 percent reported less than a year and 21 participants representing 5.10 percent reported more than 10 years.

Table 2. Demographic \& Relationship Status of Participants

\begin{tabular}{|c|c|c|c|c|}
\hline $\mathrm{S} / \mathrm{N}$ & Item & Category & Frequency & Percentage \\
\hline \multirow[t]{5}{*}{1.} & \multirow[t]{5}{*}{ Age of Participant } & $18-25$ yrs. & 83 & 20.15 \\
\hline & & $26-32$ yrs. & 135 & 32.77 \\
\hline & & $33-39$ yrs. & 129 & 31.31 \\
\hline & & $40-47$ yrs. & 38 & 9.22 \\
\hline & & 48 yrs. and above & 27 & 6.55 \\
\hline \multirow[t]{5}{*}{2.} & \multirow[t]{5}{*}{ Educational Status of Participants } & No formal Edu. & - & - \\
\hline & & FSLC & 52 & 12.62 \\
\hline & & SSCE & 179 & 43.45 \\
\hline & & Tertiary & 162 & 39.32 \\
\hline & & Post Graduate & 19 & 4.61 \\
\hline \multirow[t]{6}{*}{3} & \multirow[t]{6}{*}{ Marital Status of Participants } & Single & 103 & 25.00 \\
\hline & & Married & 153 & 37.14 \\
\hline & & Cohabiting & 18 & 4.37 \\
\hline & & separated & 77 & 18.69 \\
\hline & & Divorced & 54 & 13.11 \\
\hline & & widowed & 7 & 1.70 \\
\hline \multirow[t]{2}{*}{4} & \multirow[t]{2}{*}{ Currently Living with Perpetrators } & Yes & 253 & 61.41 \\
\hline & & No & 159 & 38.59 \\
\hline \multirow[t]{4}{*}{5} & \multirow{4}{*}{$\begin{array}{l}\text { Length of Relationship with } \\
\text { perpetrator }\end{array}$} & Less than 1 yrs. & 161 & 39.08 \\
\hline & & 1 to 5 yrs. & 147 & 35.68 \\
\hline & & 6 to $10 \mathrm{yrs}$ & 93 & 22.57 \\
\hline & & More than 10 yrs. & 11 & 2.67 \\
\hline \multirow[t]{4}{*}{6.} & \multirow[t]{4}{*}{ Length of Abuse } & Less than 1 yrs. & 102 & 24.76 \\
\hline & & 1 to 5 yrs. & 175 & 42.48 \\
\hline & & 6 to $10 \mathrm{yrs}$ & 114 & 27.67 \\
\hline & & More than 10 yrs. & 21 & 5.10 \\
\hline
\end{tabular}

Source: Field survey, 2021 


\subsubsection{Descriptive Analysis}

Table 3 and figure one reveals participants response on how often they are abused; 147 representing 35.68 percent reported not often, 87 participants, representing 21.12 percent reported very often, 63 representing 15.29 percent reported always, and 115 participants representing 27.19 percent reported once in a while

Table 3. Distribution of response on how often are you abused ( $\mathrm{N}=412)$

\begin{tabular}{lll}
\hline How Often Abuse & Frequency & Percentage (\%) \\
\hline Not often & 147 & 35.68 \\
Very often & 87 & 21.12 \\
Always & 63 & 15.29 \\
Once in a while & 115 & 27.19 \\
\hline Total & $\mathbf{4 1 2}$ & $\mathbf{1 0 0 . 0}$ \\
\hline
\end{tabular}

Source: Field survey, 2021

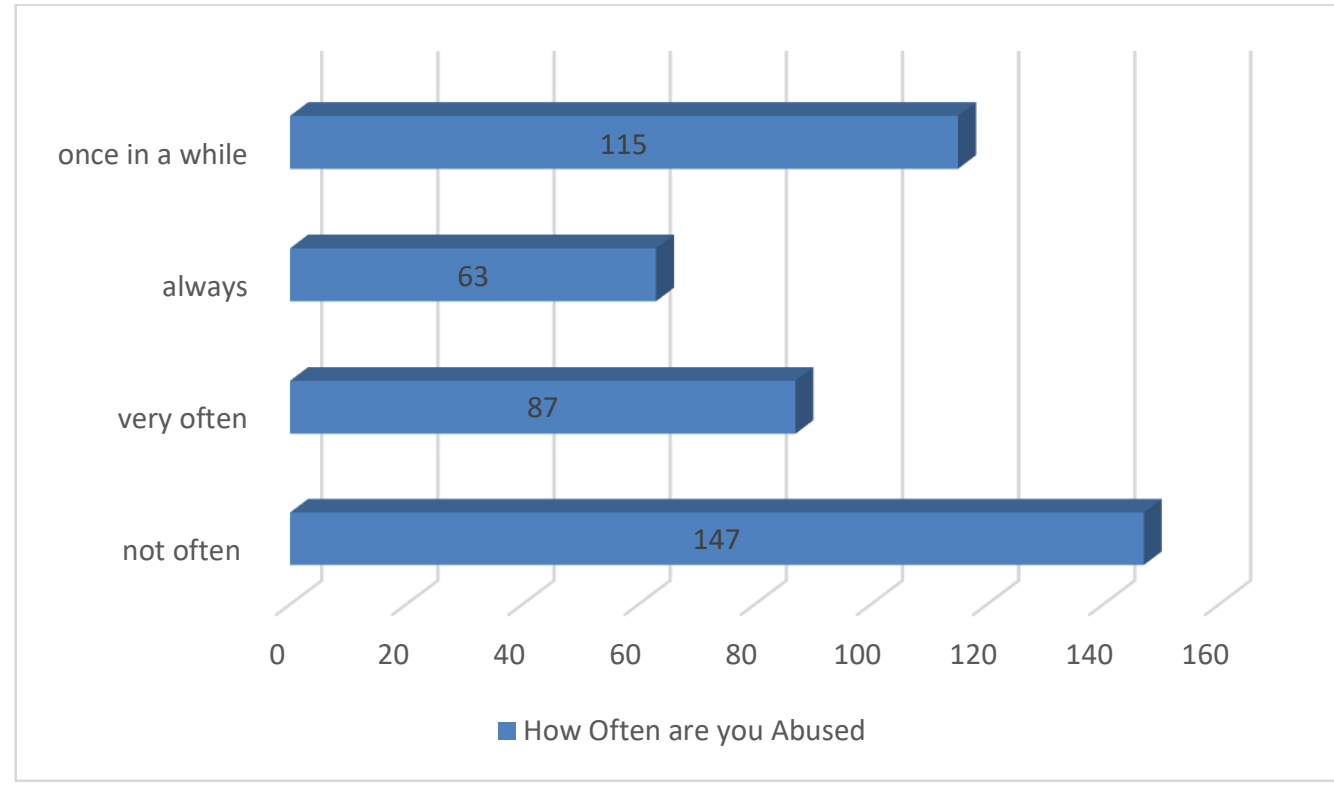

Figure 1. Response on how often participants are abused

Table 4 and figure 22 reveals participants response on the type of abuse suffered by the participants; 134 participants representing 32.52 percent reported emotional abuse , 6 participants representing 1.46 percent reported physical abuse alone, 18 participants representing 4.37 percent reported sexual abuse alone , 172 participants representing 41.75 percent reported both emotional and physical abuse and 82 participants representing 19.90 percent reported all the abuse.

Table 4: Distribution of response on Type of abuse suffered ( $N=412)$

\begin{tabular}{lll}
\hline Type of Abuse & Frequency & Percentage (\%) \\
\hline Emotional & 134 & 32.52 \\
Physical Abuse & 6 & 1.46 \\
Sexual abuse & 18 & 4.37 \\
Emotional \&Physical abuse & 172 & 41.75 \\
All of the abuse & 82 & 19.90 \\
\hline Total & $\mathbf{4 1 2}$ & $\mathbf{1 0 0 . 0}$ \\
\hline
\end{tabular}

Source: Field survey, 2021 


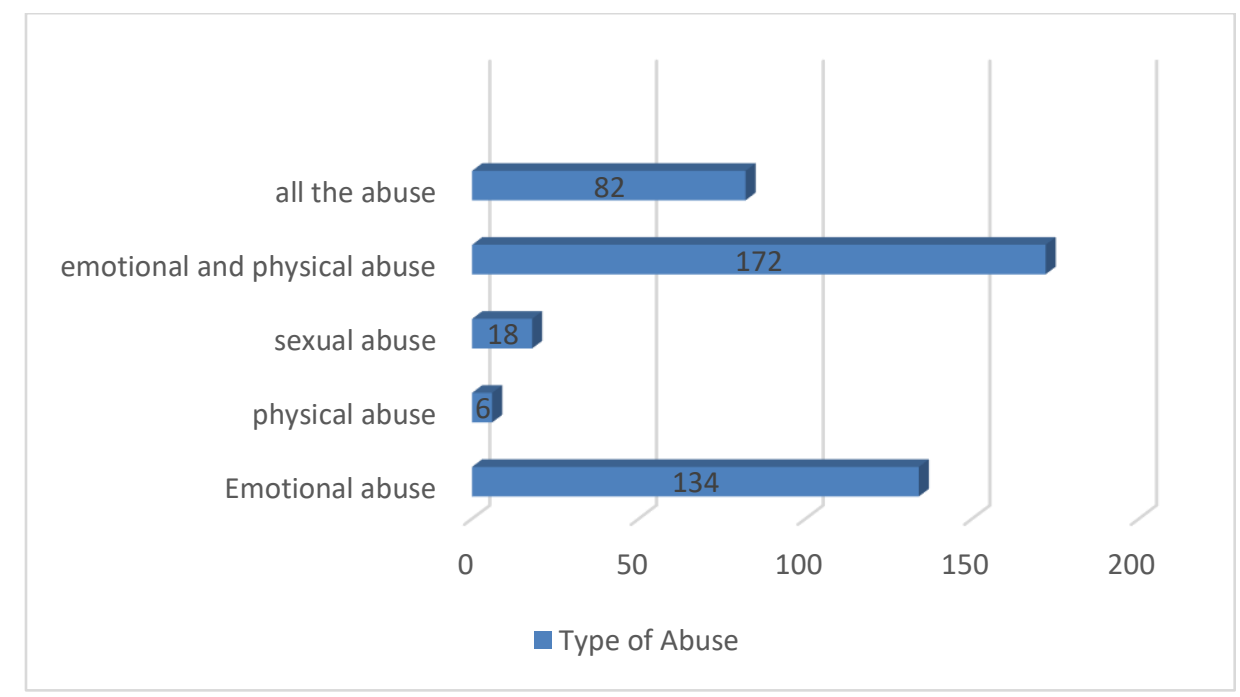

Figure 2. Response on type of abuse

Table 5 and figure 3 reveals participants response on abuser; 168 participants response on abuser; 168 participants, representing 4.78 percent reported husbands, 134 participants representing 32.52 percent reported fiancé and 110 participants representing 26.70 percent reported sexual partner.

Table 5. Distribution of response on the abuser $(\mathrm{N}=412)$

\begin{tabular}{lll}
\hline Abuser & Frequency & Percentage (\%) \\
\hline Husband & 168 & 40.78 \\
Fiancé & 134 & 32.52 \\
Sexual partner & 110 & 26.70 \\
\hline Total & $\mathbf{4 1 2}$ & $\mathbf{1 0 0 . 0}$ \\
\hline Source: Field survey, 202l & &
\end{tabular}

Source: Field survey, 2021

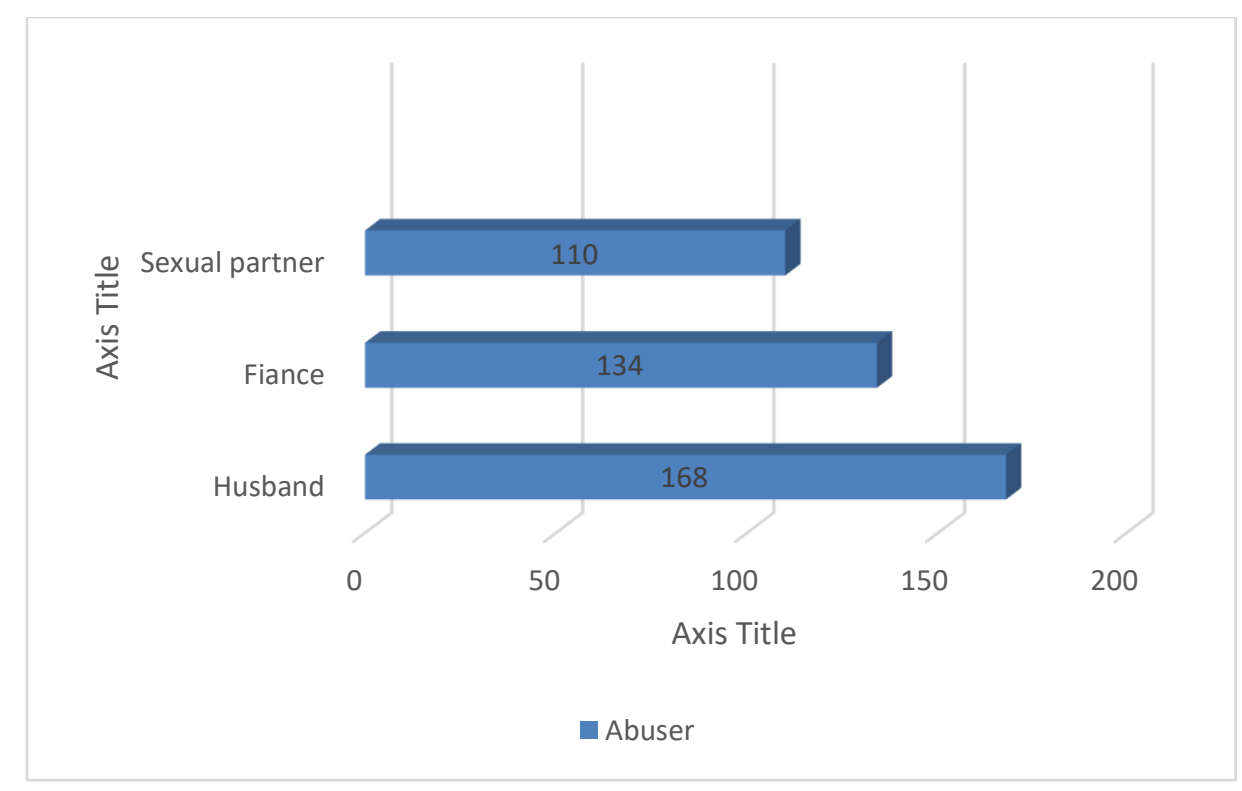

Figure 3. Response on Abuser

Table 6 and figure 4 reveals if participants are currently with abuser; 153 participants representing 37.14 percent reported yes, and 211 representing 51.21 percent reported No, and 48 respondents representing 11.65 per cent reported Do not want to disclose. 
Table 6. Distribution of response on currently with abuser $(\mathrm{N}=412)$

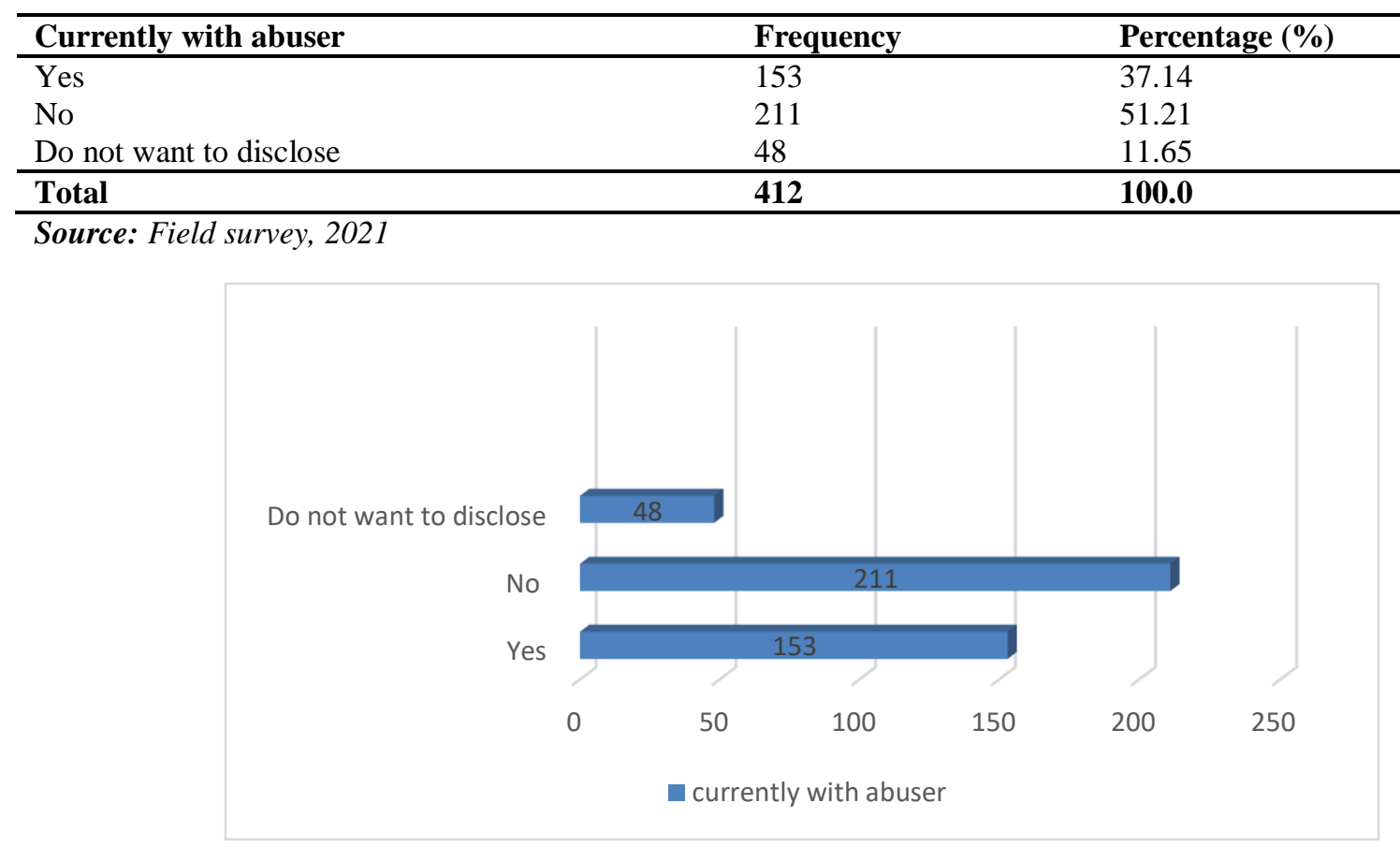

Figure 4. Response on if Participant is currently with Abuser

Table 7 and figure 5 reveals participants response on if abused in the last 12 months; 91 participants representing 22.09 reported yes; and 32, participants representing 77.91 reported no.

Table 7. Distribution of response on abused in the last 12 months $(\mathrm{N}=412)$

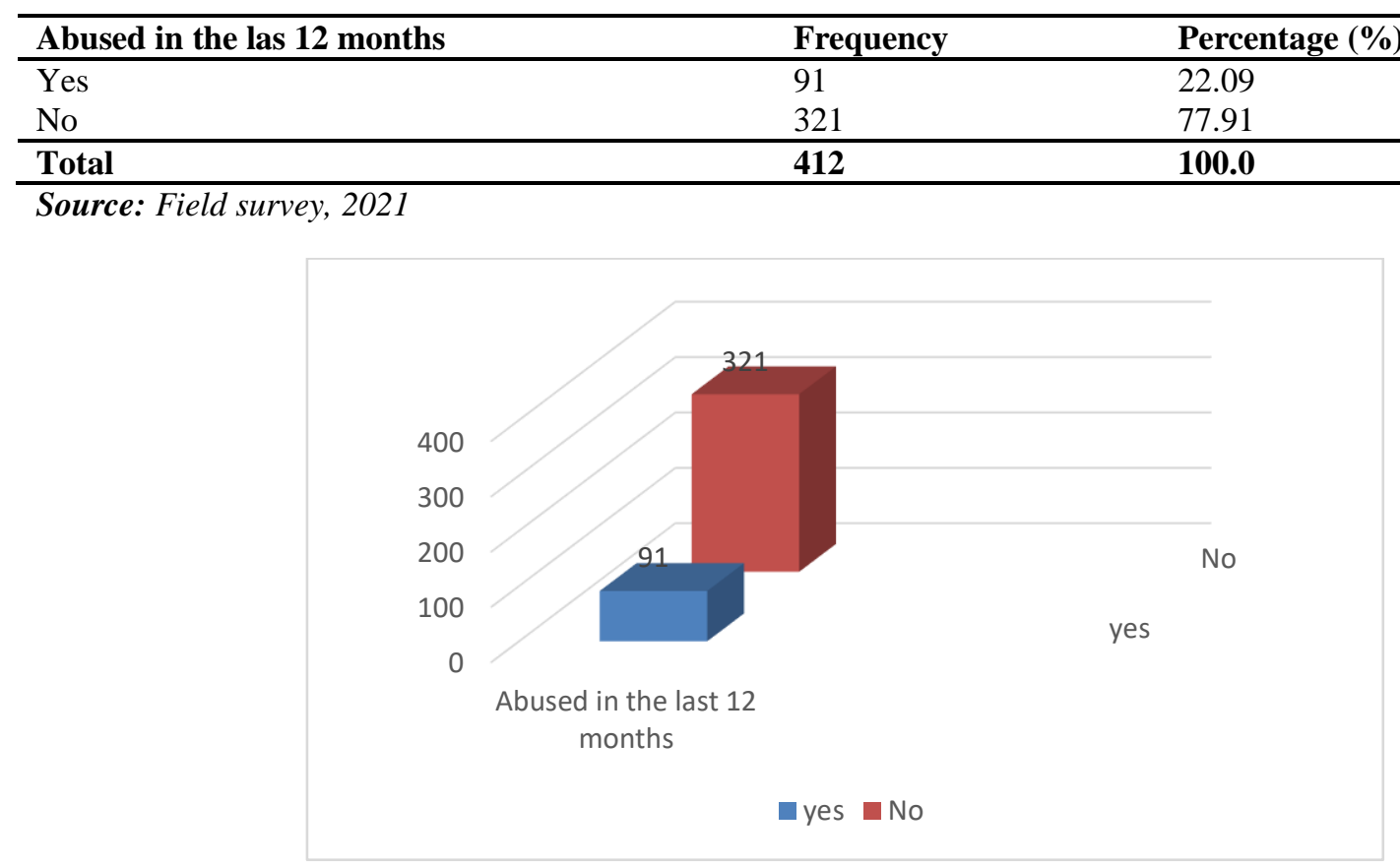

Figure 5. Respondent response on abuse in the last 12 months 
Table 8 and figure 6 revealed it in any time of abuse, abused need medical attention; 68 participants representing 16.50 percent report Yes and 344 participants, 83.50 percent reported No.

Table 8. Distribution of response on in any one time of abuse, abused needed medical attention $(\mathrm{N}=412)$

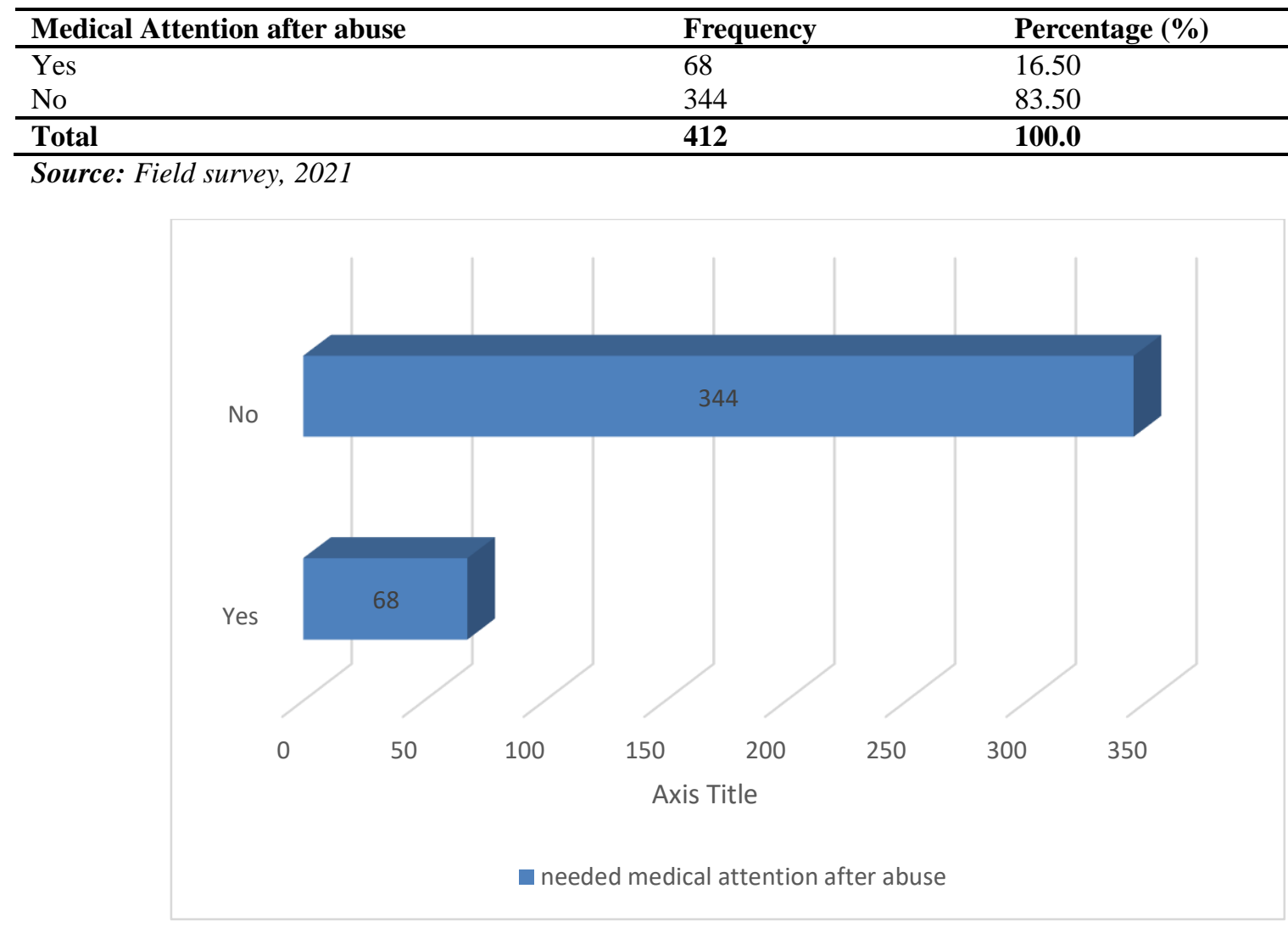

Figure 6. Respondent response on abuse in the last 12 months

Table 9 and figure 7 revealed the mental health effect of abuse; 142 participants representing 34.47 percent reported that they suffered from depression, 85 participants representing 20.63 percent reported suffering mood disorder , 10 participants representing 2.43 percent reported having suicidal ideation , 7 participants representing 1.70 percent reported having post-traumatic stress disorder , 98 participants representing 23.79 percent reported anxiety disorder, 31 participants representing 7.52 percent reported others, 39 participants representing 9.47 percent reported No mental health issue.

Table 9. Distribution of response on mental health effect of abuse $(\mathrm{N}=412)$

\begin{tabular}{lll}
\hline Mental health Effect & Frequency & Percentage (\%) \\
\hline Depression & 142 & 34.47 \\
Mood Disorder & 85 & 20.63 \\
Suicide Ideation & 10 & 2.43 \\
Post-traumatic stress disorder & 7 & 1.70 \\
Anxiety disorder & 98 & 23.79 \\
Others & 31 & 7.52 \\
No mental health issues & 39 & 9.47 \\
\hline Total & $\mathbf{4 1 2}$ & $\mathbf{1 0 0 . 0}$ \\
\hline
\end{tabular}

Source: Field survey, 2021 


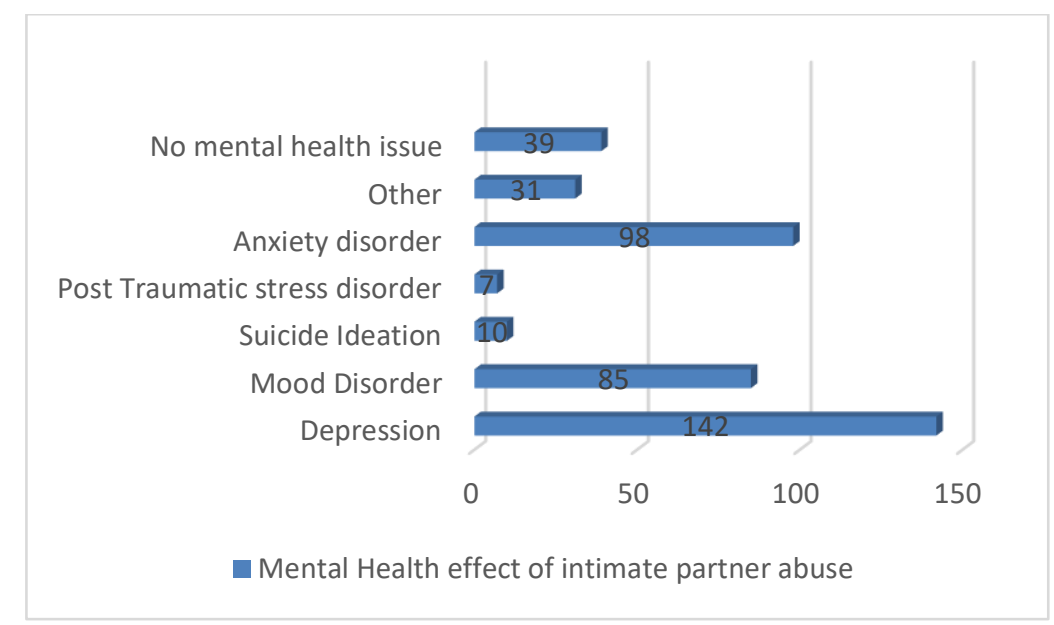

Figure 7. Respondent response on Mental Health effect of abuse

Table 10 and figure 8 revealed participants response on reporting abuse; 35 participants representing 8.50 percent reported reporting Yes and 377 representing 91.50 percent reported No.

Table 10. Distribution of response on reporting abuse $(\mathrm{N}=412)$

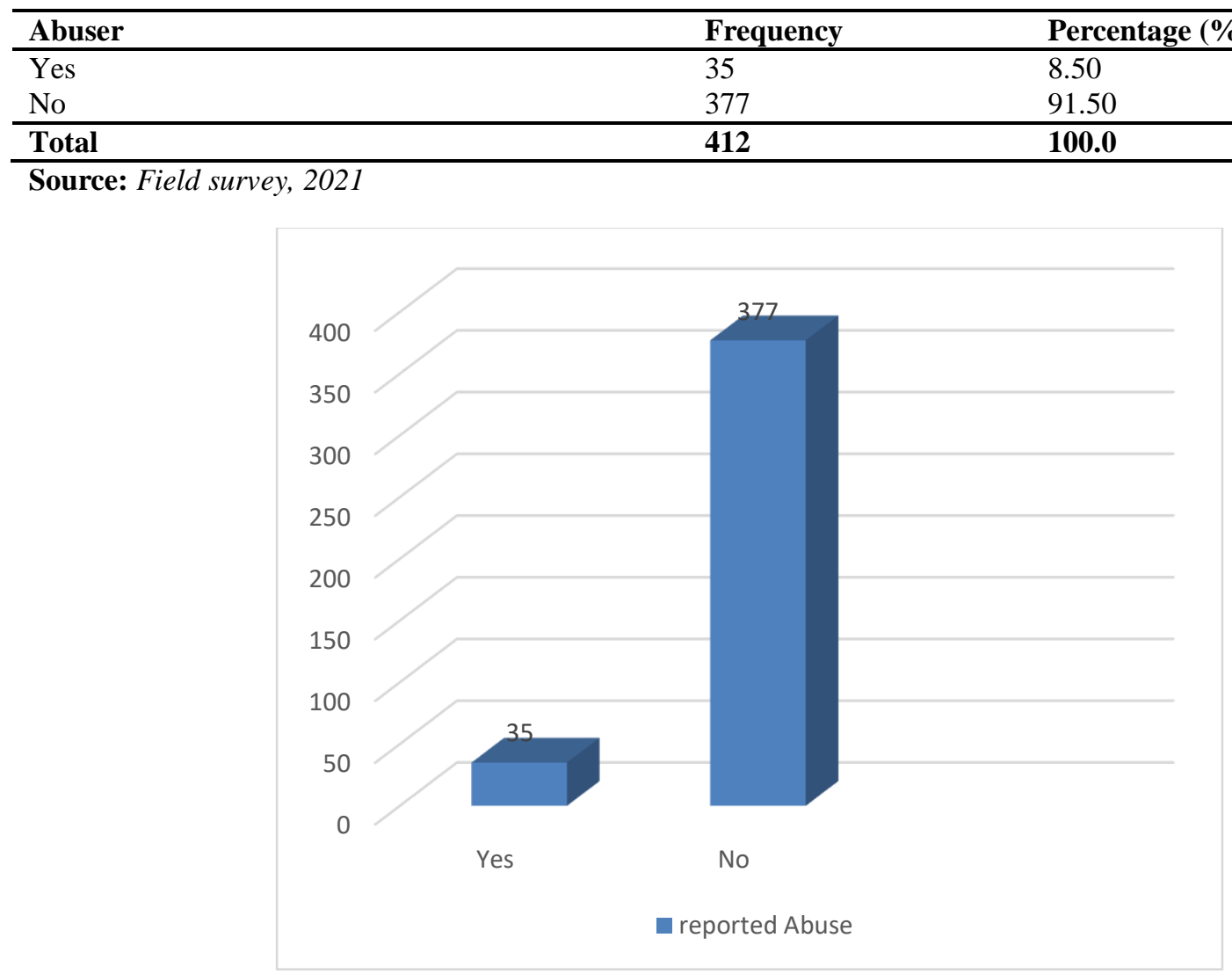

Figure 8. Respondent response on Mental Health effect of abuse

\subsection{Discussion of Findings}

Violence by intimate partner affect women significantly globally. Despite the serious nature of the problem, especially in rural and patriarchal societies, there is paucity of data describing the socio-economic effect of intimate partner 
violence. The paucity of data in such areas is as a result of cultural acceptance if intimate partner violence and under reporting of violence by victims. This study attempt to provide data on the mental effect of intimate partner violence in Obudu, Cross River State. Data collected was analyzed using descriptive analysis. Data on the demographic data of the participants revealed that most of the participants, 87.38 percent has a minimum of senior secondary school qualification, with 37.14 percent of the participants married and a small percentage in a relationship and cohabiting with their partner. A large percentage of the participants, 61.41 percent as of the time of the study were living with the perpetrators of violence against them with most of the participants, 67.24 percent reported being abused from 0 to 5 years.

Data collection and analysed on the main variables focused on type of abuse, suffered abuser, how often is the abuse effect of abuse on mental health. A lot of women suffer from violence from an intimate partner. A significant percentage $(36.41 \%)$ women suffer abuse very often with majority $(41.75 \%)$ suffering both physical and emotional abuse. This is often followed by emotional abuse alone (32.52\%), 4.37 percent of the women have been subjected to sexual abuse. A large percentage, $(40.78 \%)$ of the women reported that they are abused by their husband, this could be attributed to the fact that Obudu is a patriarchal society and culturally men are given prominence over women and incidence of abuse, though not openly encourage, abuse yet do not frawn at it. That is why a large percentage $(37.14 \%)$ are at the time of the study with their abuser.

In the last 12 months, 22.09 percent of the women have suffered abuse from an intimate partner and 16.50 percent of the victims needed medical attention after abused. On the mental health effect of abuse on the victim only 9.47 percent of women reported not suffering from any mental health illness after being abused by an intimate partner. 34.47 percent of women suffered from depression as as result of abuse, 23.79 percent suffered from anxiety disorder, 20.63 percent suffered from mood disorder. 2.43 percent suffered from suicidal ideation, 1.70 percent suffered from post-traumatic stress disorder and 7.53 percent suffering from other mental health issues. From all who suffered from abuse, only 8.50 percent were able to report abuse with these results we can conclude that intimate partner violence significantly causes mental health issues.

The correlation between intimate partner violence and any form of mental health issues as found by this study is corroborated by existing studies. Sharma, Vaksa Kalivann and Bhardwaj (2019) in their study that assessed the association between mental health and domestic violence found that domestic violence affects mental health of victims. Dillion, Hussani, Loxton and Rahman (2013) found that intimate partner violence is associated with a under range of mental health issues. Avidebegovic and Sumanorovic (2006) found that domestic violence in all form had long term health effect on the victim.

\section{Conclusion and Recommendation}

This study has found that intimate partner violence prevalent in Obudu and in all its form intimate partner violence significantly have long term mental health effect on women who were abused. Hence there is need for increase public awareness on the dangers of intimate partner violence by government and appropriate laws that target rural communities should be put in place to combat the problem. There is need for healthcare providers in rural communities to be trained on identifying, intervene victims of violence given that most women in one-time visits hospitals in rural communities

\section{References}

Abrahams, N., Jewkes, R., Laubscher, R., \& Hoffman, M. (2006). Intimate partner violence: prevalence and risk factors for men in Cape Town, South Africa. Violence and victims, 21(2), 247-264. https://doi.org/10.1891/vivi.21.2.247

Ahinkorah, B. O., Dickson, K. S., \& Seidu, A. A. (2018). Women decision-making capacity and intimate partner violence among women in sub-Saharan Africa. Archives of Public Health, 76(1), 123. https://doi.org/10.1186/s13690-018-0253-9

Ali, T. S., Mogren, I., Krantz, G. (2013). Intimate partner violence and mental health effects: A population-based study among married women in Karachi, Pakistan. International Journal of Behavioral Medicine, 20(1), 131-139 
Avdibegović, E., \& Sinanović, O. (2006). Consequences of domestic violence on women's mental health in Bosnia and Herzegovina. Croatian medical journal, 47(5), 730-741

Benebo, F. O., Schumann, B., \& Vaezghasemi, M. (2018). Intimate partner violence against women in Nigeria: a multilevel study investigating the effect of women's status and community norms. BMC Women's Health, 18(1), 1-17. https://doi.org/10.1186/s12905-018-0628-7

Benebo, F. O., Schumann, B., \& Vaezghasemi, M. (2018). Intimate partner violence against women in Nigeria: a multilevel study investigating the effect of women's status and community norms. BMC Women's Health, 18(1), 123. https://doi.org/10.1186/s12905-018-0628-7

Chepuka, L., Taegtmeyer, M., Chorwe-Sungani, G., Mambulasa, J., Chirwa, E., \& Tolhurst, R. (2014). Perceptions of the mental health impact of intimate partner violence and health service responses in Malawi. Global Health Action, 7(1), 24816. https://doi.org/10.3402/gha.v7.24816

Coker, A. L., Davis, K. E., Arias, I., Desai, S., Sanderson, M., Brandt, H. M., \& Smith, P. H. (2002). Physical and mental health effects of intimate partner violence for men and women. American Journal of Preventive Medicine, 23(4), 260-268. https://doi.org/10.1016/s0749-3797(02)00514-7

Dillon, G., Hussain, R., Loxton, D., \& Rahman, S. (2013). Mental and Physical Health and Intimate Partner Violence against Women: A Review of the Literature. International Journal of Family Medicine, 2013, 1-15. https://doi.org/10.1155/2013/313909

Dokkedahl, S., Kok, R. N., Murphy, S., Kristensen, T. R., Bech-Hansen, D., \& Elklit, A. (2019). The psychological subtype of intimate partner violence and its effect on mental health: protocol for a systematic review and meta-analysis. Systematic Reviews, 8(1), 1-10. https://doi.org/10.1186/s13643-019-1118-1

Huecker M.R., King, K. C., Jordan, G. A, et al. (2021). Domestic Violence. In: StatPearls [Internet]. Treasure Island (FL): StatPearls Publishing; 2021 Jan-. Available from: https://www.ncbi.nlm.nih.gov/books/NBK499891/

Izugbara, C. O., Obiyan, M. O., Degfie, T. T., \& Bhatti, A. (2020). Correlates of intimate partner violence among urban women in sub-Saharan Africa. PloS one, 15(3), e230508. https://doi.org/10.1371/journal.pone.0230508

Navarro-Mantas, L., de Lemus, S., \& Megías, J. L. (2021). Mental Health Consequences of Intimate Partner Violence Against Women in El Salvador. Violence against women, 1077801220978803. Advance online publication. https://doi.org/10.1177/1077801220978803

Ojong-Ejoh, M.U., Iji, M.E., \& Angioha, P.U. (2019). "Curing socio-economic ills in Obudu Local Government Area: An assessment of non-governmental agencies activities". Journal of Social Service and Welfare, 1(2), 2019, pp. 38-45.

Okemgbo, C. N., Omideyi, A. K., \& Odimegwu, C. O. (2002). Prevalence, Patterns and Correlates of Domestic Violence in Selected Igbo Communities of Imo State, Nigeria. African Journal of Reproductive Health, 6(2), 101. https://doi.org/10.2307/3583136

Okenwa, L. E., Lawoko, S., \& Jansson, B. (2009). Exposure to Intimate Partner Violence Amongst Women of Reproductive Age in Lagos, Nigeria: Prevalence and Predictors. Journal of Family Violence, 24(7), 517530. https://doi.org/10.1007/s10896-009-9250-7

Omang, T.A., Angioha, P.U., Ojong-Ejoh, M.U. \& Abang, T. (2020). COVID-19Measures and the Exacerbation of Intimate Partner Violence in Calabar, Ijo-International Journal Of Social Science And Humanities Research., 3(12)83-94

Ruiz-Pérez, I., \& Plazaola-Castaño, J. (2005). Intimate partner violence and mental health consequences in women attending family practice in Spain. Psychosomatic medicine, 67(5), 791-797. https://doi.org/10.1097/01.psy.0000181269.11979.cd

Sharma, K. K., Vatsa, M., Kalaivani, M., \& Bhardwaj, D. (2019). Mental health effects of domestic violence against women in Delhi: A community-based study. Journal of family medicine and primary care, 8(7), 2522-2527. https://doi.org/10.4103/jfmpc.jfmpc_427_19 
Tanimu, T. S., Yohanna, S., \& Omeiza, S. Y. (2016). The pattern and correlates of intimate partner violence among women in Kano, Nigeria. African Journal of Primary Health Care \& Family Medicine, 8(1), 1-6. https://doi.org/10.4102/phcfm.v8i1.1209

The National Intimate Partner and Sexual Violence Survey (2010) Summary Report is a publication of the National Center for Injury Prevention and Control of the Centers for Disease Control and Prevention

United Nations Population Fund (2019). Gender-based violence. https://esaro.unfpa.org/en/topics/gender-basedviolence

World Health Organization (2002). World report on violence and health. Available from: http://apps. who.int/iris/bitstream/handle/10665/42495/9241545615_eng.pdf?sequence=1 